\title{
Bioavailability of metsulfuron and sulfentrazone herbicides in soil as affected by amendment with two contrasting willow biochars.
}

\section{UNIVERSITY OF}

SASKATCHEWAN
Anna M. Szmigielski ${ }^{1}$, Ryan D. Hangs, Jeff J. Schoenau ${ }^{1}$

'Dept. of Soil Sci., University of Saskatchewan

\section{Introduction}

There are multiple environmental and agronomical benefits of biochar addition to soil. Due to their porous structure, biochars sorb and retain a variety of organic compounds from soil including soil-applied herbicides.

The degree of sorption may vary depending on the biochar physical and chemical properties and its application rate [1].

\section{Objectives}

This study investigated the effect of two willow biochars (Salix spp) produced using either fast $\left(\right.$ at $400^{\circ} \mathrm{C}$ ) or slow (up to $750^{\circ} \mathrm{C}$ ) pyrolysis on the bioavailability of metsulfuron and sulfentrazone herbicides in soil.

\section{Materials and Methods}

- Five rates $(0,1,2,3,4 \% ; \mathrm{w} / \mathrm{w})$ of each biochar (Table 1) were used, along with varying rates of metsulfuron $\left(0\right.$ to $3.2 \mu \mathrm{g}$ ai $\left.\mathrm{kg}^{-1}\right)$ and sulfentrazone $\left(0\right.$ to $200 \mu \mathrm{g}$ ai $\left.\mathrm{kg}^{-1}\right)$.

- To measure herbicide bioactivity in soil with added biochar, a sugar beet bioassay in WhirlPak ${ }^{\mathrm{TM}}$ bags was used [2] (Fig. 1).

Table 1. Selected physical and chemical properties of willow biochar produced using slow (at $400^{\circ} \mathrm{C}$ ) or fast (up to $750^{\circ} \mathrm{C}$ ) pyrolysis.

\begin{tabular}{cccccccccc}
\hline Biochar & $\begin{array}{c}\mathrm{C} \\
\%\end{array}$ & $\begin{array}{c}\mathrm{H} \\
\%\end{array}$ & $\begin{array}{c}\mathrm{O} \\
\%\end{array}$ & $\begin{array}{c}\mathrm{N} \\
\%\end{array}$ & $\begin{array}{c}\text { Ash } \\
\%\end{array}$ & $\mathrm{pH}$ & $\begin{array}{c}\mathrm{SSA}^{*} \\
\mathrm{~m}^{2} \mathrm{~g}^{-1}\end{array}$ & $\begin{array}{c}\mathrm{CEC} \\
\text { Meq 100 }\end{array}$ & $\begin{array}{c}\text { Bulk density } \\
\mathrm{g} \mathrm{cm}^{-3}\end{array}$ \\
\hline Fast & 70.7 & 3.6 & 12.0 & 1.4 & 10.9 & 9.5 & 3 & 26 & 1.39 \\
Slow & 81.3 & 1.9 & 3.9 & 0.7 & 10.6 & 9.7 & 175 & 20 & 1.16 \\
\multicolumn{2}{l}{ "Specific Surface Area }
\end{tabular}

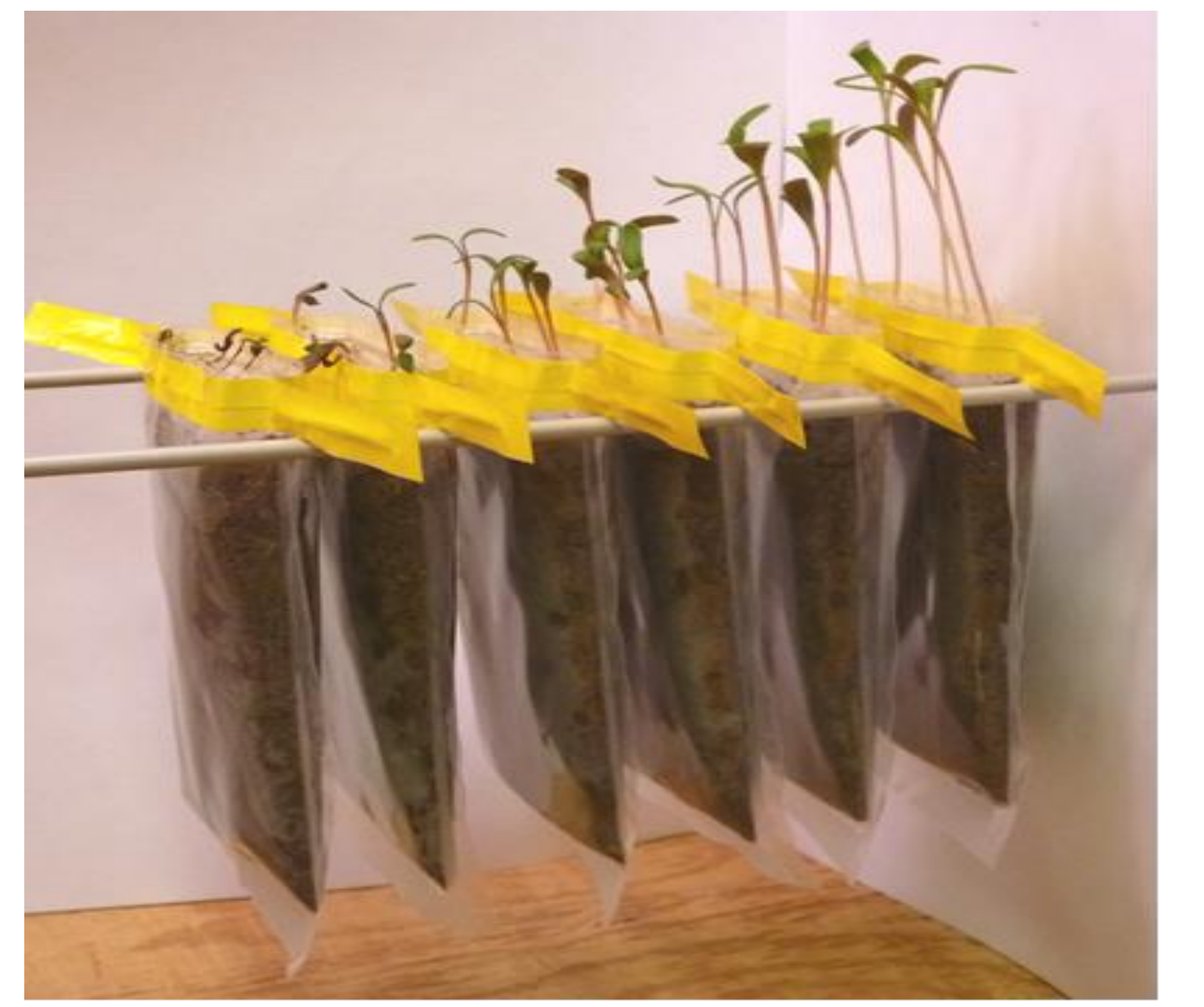

Fig. 1. Bioassay performed in WhirlPak bags

\section{Results}

- The fast-pyrolysis biochar had minimal effect (Fig. 2a and 3a), while the slow-pyrolysis biochar decreased the bioavailability of both herbicides (Fig. $2 b$ and $3 b$ ).

- Despite using the same feedstock, the two biochars had different physical and chemical properties (Table 1), of which specific surface area was most contrasting (3.0 and $175 \mathrm{~m}^{2} \mathrm{~g}^{-1}$ for fast- and slow-pyrolysis biochar respectively).
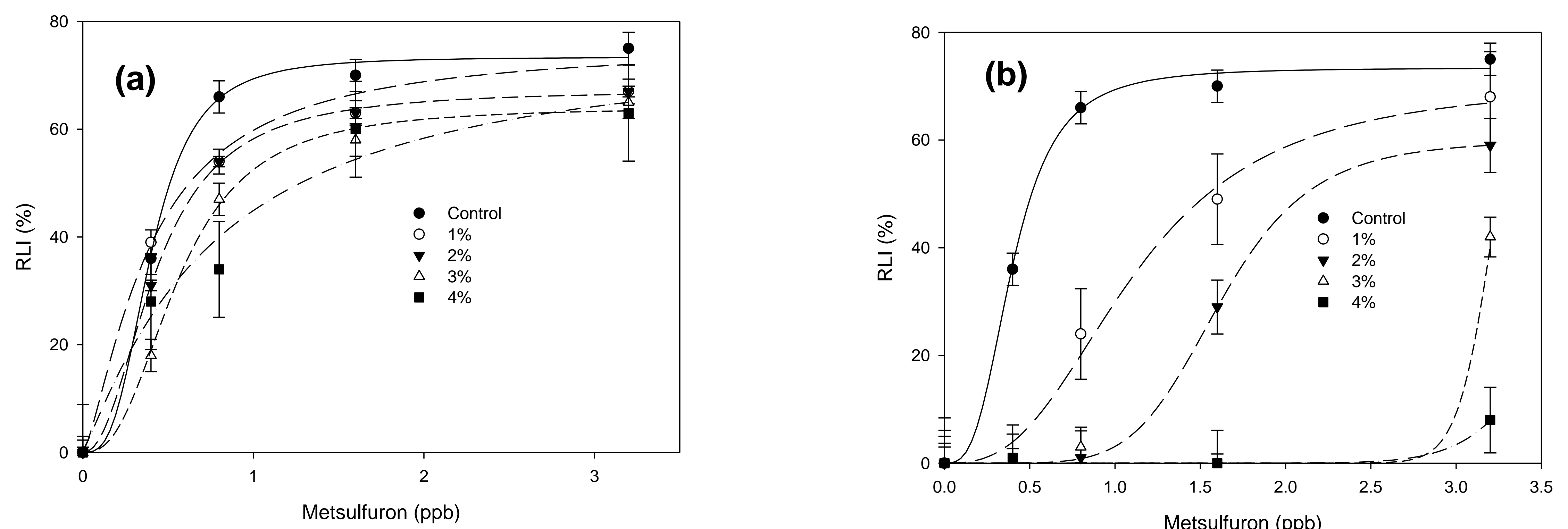

Fig 2 Sugar beet root length inhibition in response to metsulfuron in soil amended with increasing concentration of (a) fast-pyrolysis biochar (b) slow-pyrolysis biochar.
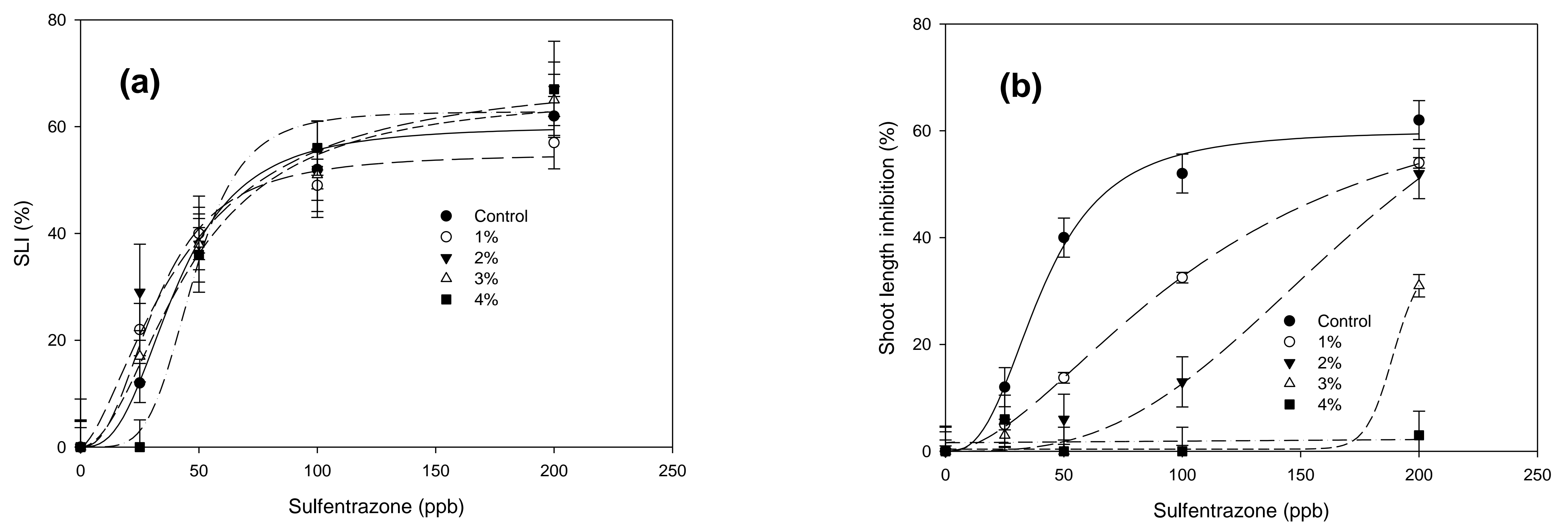

Fig. 3. Sugar beet shoot length inhibition in response to sulfentrazone in soil amended with increasing concentration of (a) fast-pyrolysis biochar (b) slow-pyrolysis biochar.

\section{Conclusions}

Although increased adsorption associated with the high-surface area biochars is useful from the environmental perspective, further research on how biochars influence the efficacy of soil-active herbicides is needed as biochar may have negative effect on weed control for years to come. 